\title{
Evaluation of a Novel Endodontic Paste for Primary Teeth with Necrotic Pulp
}

\author{
Jessa lashmin Alcobaça Gomes Machado ${ }^{1, *}$, Roger Wallacy Guimarães Oliveira ${ }^{2}$, André Luis Menezes Carvalho ${ }^{1,3}$, Patrick Veras \\ Quelemes ${ }^{1}$, Marina de Deus Moura de Lima ${ }^{1}$, Marcoeli Silva de Moura ${ }^{1}$, Cacilda Castelo Branco Lima ${ }^{1}$, Carla Verônica Rodarte de Moura ${ }^{2}$, \\ Lúcia de Fátima Almeida de Deus Moura' \\ 'Postgraduate Programme in Dentistry, Federal University of Piauí, UFPI, Teresina, BRAZIL. \\ 2Department of Chemistry, Federal University of Piauí, UFPI, Teresina, BRAZIL. \\ 3Postgraduate Programme in Pharmaceutical Sciences, Federal University of Piauí, UFPI, Teresina, BRAZIL.
}

\begin{abstract}
Background: The ideal root canal filling for endodontic treatment of primary teeth with necrotic pulp must have antimicrobial activity, not cause tooth discoloration or interfere with the eruption of permanent successor teeth. This study aimed to evaluate physiochemical properties of a novel paste (CZ Paste) for endodontic treatment of primary teeth with necrotic pulp and compare its antimicrobial activity to Chloramphenicol, Tetracycline, Zinc oxide (CTZ) and Zinc Oxide eugenol (ZOE) pastes. Methods: CZ, CTZ and ZOE pastes were homogenized with eugenol at the time of testing. Fourier Transform Infrared spectroscopy (FTIR) and Differential Scanning Calorimetry (DSC) tests were performed. Antimicrobial activity was assessed using agar diffusion test (ADT), direct contact test (DCT) and bactericidal effect assessment against Staphylococcus aureus, Enterococcus faecalis and Pseudomonas aeruginosa. Results: FTIR showed that $\mathrm{CZ}$ paste has a similar profile to chloramphenicol spectrum and in DSC thermograms it demonstrated a slight change in endothermic transition temperature. In the ADT, CTZ paste and CZ paste presented
\end{abstract}

similar inhibition zone diameters and were higher than ZOE paste $(P<$ 0.05). All pastes inhibited the growth of tested micro-organisms in DCT. Bactericidal assessment test showed that only CZ and CTZ pastes had bactericidal effect. Conclusion: $\mathrm{CZ}$ paste could be an alternative for endodontic treatment of primary teeth with necrotic pulp.

Key words: Primary tooth, Pulpectomy, Root canal filling materials, Antibiotic paste, Bacteria.

Correspondence

Mrs. Jessa Machado, M.sC

Postgraduate Programme in Dentistry, Federal University of Piauí, UFPI, Teresina, BRAZIL.

Phone: +55-86-32371517

Email: jes.iagm@gmail.com

DOI: 10.5530/jyp.2020.12.64

\section{INTRODUCTION}

Conventional chemo-mechanical preparation of root canals in primary molars is advocated in cases of irreversible pulpitis or pulp necrosis in children. ${ }^{1}$ However, as these procedures are laborious due to the complex anatomical characteristics of primary teeth, ${ }^{2}$ dentists often choose to perform early extractions, which may trigger problems with occlusion and aesthetics. ${ }^{3}$ Among the root canal filling materials recommended, zinc oxide eugenol paste (ZOE paste) is highlighted, however, there is no consensus regarding the best paste to use in pulpectomies of primary teeth with necrotic pulp. ${ }^{4}$ The ideal endodontic material for primary teeth must have biocompatibility with periodical tissues, antimicrobial activity, not cause tooth discoloration or interfere with the eruption of permanent successor teeth. ${ }^{5}$ In order to increase the success rates of endodontic treatment in children, broad-spectrum antibiotics have been incorporated into these pastes to reduce and/or eliminate the micro biota and their insertion is limited to the pulp chamber, becoming technically more accessible to general practitioners. ${ }^{6-10} \mathrm{CTZ}$ paste is a pharmacological dental material developed by Cappiello ${ }^{6,7}$ composed by chloramphenicol, tetracycline and zinc oxide. However, as pastes that contains tetracycline or its derivates have the disadvantage of stain tooth structures the use of these substances has been discouraged. ${ }^{11}$

Due to this reason, this study questioned whether modifying the original CTZ paste formulation would affect its properties in order do establish a novel paste to be used in dentistry. Therefore, the aim of this study was to evaluate physiochemical properties of a novel paste (CZ Paste) for endodontic treatment of primary teeth with necrotic pulps and compare its antimicrobial activity to CTZ and ZOE pastes.

\section{MATERIALS AND METHODS}

\section{Preparation of tested materials}

CZ paste was composed of a ratio of one part of chloramphenicol and two parts of zinc oxide powders (Biodinamica, Ibiporã, Paraná, Brazil). CTZ paste powder was prepared in a specialised pharmacy (Galeno Pharmacy, Teresina, Piauí, Brazil) and individually encapsulated maintaining a ratio of one part of tetracycline, one part of chloramphenicol and two parts of zinc oxide. ${ }^{6} \mathrm{ZOE}$ paste was composed of zinc oxide powder and eugenol (Biodinamica, Ibiporã, Paraná, Brazil).

An analytical balance (AG 200, Gehaka Electric, Electronic Industry and Commerce, São Paulo, Brazil) was used to weigh the components used they were prepared on sterile glass slabs at the time of testing. Powders were mixed following the power/liquid ratio of $1 \mathrm{mg}$ of powder to $4 \times 10^{-4}$ $\mathrm{ml}$ eugenol (Biodynamics, Ibiporã, Paraná, Brazil), to ensured that all pastes had a similar consistence to toothpaste.

\section{Physiochemical properties of CZ paste \\ Fourier transform infrared (FTIR) spectroscopy}

CZ paste and its constituents (Chloramphenicol, Zinc Oxide and Eugenol) were analysed by FT-IR spectrometer (Perkin Elmer Spectrum 100 GTX) in range of $4000 \mathrm{~cm}^{-1}$ and $400 \mathrm{~cm}^{-1}$ at $4 \mathrm{~cm}^{-1}$ resolution with 
16 scans co-added and as $\mathrm{KBr}$ pellet. Collected spectra were investigated for possible chemical interactions between drugs and other components of formulation.

\section{Differential scanning calorimetry (DSC)}

A quantity of $5 \mathrm{mg}$ of each sample (CZ paste and Chloramphenicol) was placed in an aluminium pan and all samples were heated at the rate of $10^{\circ} \mathrm{C} / \mathrm{min}$ under nitrogen stream $\left(50 \mathrm{~mL} / \mathrm{min}\right.$ ) (DSC-60, Shimadzu ${ }^{\circ}$ ). The heating temperature was carried out in the range of 0 to $500^{\circ} \mathrm{C}$. Zinc oxide could not be analysed because its melting point is too high and eugenol because it is a liquid at room temperature.

\section{Antimicrobial activity}

The antimicrobial activity of CZ paste was compared to CTZ and ZOE pastes using the agar diffusion test (ADT), direct contact test (DCT) and bactericidal effect assessment.

The bacterial strains of Staphylococcus aureus ATCC 6538, Enterococcus faecalis ATCC 29212 and Pseudomonas aeruginosa ATCC 27853 (American-type culture collection, Oswaldo Cruz Foundation, Rio de Janeiro, Brazil) were used.

Samples were cultured in Brucella broth supplemented with $2.5 \%$ yeast extract (Becton Dickinson and Company, Sparks, MD, USA) under aerobic conditions at $37^{\circ} \mathrm{C}$ for $24 \mathrm{hr}$. Then, the samples were inoculated in Brucella agar plates supplemented with 2.5\% yeast extract (Becton Dickinson and Company, Sparks, MD, USA) and incubated. Afterwards, from isolated colonies, a suspension of each bacterial strain with a McFarland optical density of $0.5\left(1.2 \times 10^{8} \mathrm{CFU} / \mathrm{mL}\right)$ was made into an $0.85 \%$ isotonic sodium chloride solution and used for all the experiments described below.

For the ADT test, ${ }^{12}$ four $6 \mathrm{~mm}$ wells (one for each paste tested) were made on Mueller-Hinton agar plates (Becton Dickinson and Company, Sparks, MD, USA) and filled with the pastes. Then, $100 \mu \mathrm{L}$ aliquots of each microbial species were inoculated into $8 \mathrm{~mL}$ tubes containing a semi-solid medium (Mueller-Hinton broth supplemented with $1 \%$ yeast extract and $0.8 \%$ Bacto agar, Becton Dickinson and Company, Sparks, MD, USA). These were homogenised and deposited over the plates with the previously filled wells. The seeded plates were maintained at room temperature for $1 \mathrm{hr}$ and then incubated for $48 \mathrm{hr}$ at $37^{\circ} \mathrm{C}$ in aerobic conditions. The experiments were carried out in triplicate.

Following the incubation period, the diameters of the inhibition zones were measured (in $\mathrm{mm}$ ) using a calliper and the diameter mean was calculated. Data were analysed using the Graph Pad Prisma 5.0 software. Shapiro-Wilk test was applied to assess the normality of the variables. An analysis of variance (ANOVA) followed by Bonferroni's post-hoc test was used to assess the differences between the means of the groups $(P<$ $0.05)$.

For DCT test, ${ }^{13}$ 96-well micro dilution plates were positioned vertically, the walls of the wells were coated with the same quantity of the three pastes tested (four wells for each paste). Then, $10 \mu \mathrm{L}$ of each microbial suspension was inoculated into the pastes and the plates were then incubated for $1 \mathrm{hr}$ under aerobic conditions at $37^{\circ} \mathrm{C}$. Next, $245 \mu \mathrm{L}$ of tryptone soya broth (TSB; Difco Laboratories, Detroit, MI, USA) were added to each well and the bacterial concentration was about $6 \times 10^{6}$ $\mathrm{CFU} / \mathrm{mL}$.

The culture medium (TSB) was used as the sterile control and the growth control (positive control) consisted of wells containing only the tested micro-organisms in TSB. A negative control containing only the pastes and broth was also performed. Absorbance readings were taken at the baseline and at 5, 10 and $24 \mathrm{hr}$ at a wavelength of $630 \mathrm{~nm}$ (EL800 Universal Microplate Reader, Bio-Tek Instruments, Inc.). The plates were vortexed for 2 min prior to each reading. Mean and standard deviation of the optical density (OD) values obtained for each sample were calculated. Following $24 \mathrm{hr}$ of incubation of the micro plates used in DCT test, the bactericidal effect of the same pastes was also verified. $100 \mu \mathrm{L}$ of suspension contained in each well was removed and inoculated into tryptone soy agar (TSA) (Becton Dickinson and Company, Sparks, $\mathrm{MD}$, USA) plates, then incubated at $37^{\circ} \mathrm{C}$ for $48 \mathrm{hr}$ under aerobic. This experiment was also carried out in quadruplicate. The colonies counting was performed. A bactericidal effect was considered when a reduction equal to or greater than $3 \log _{10} \mathrm{CFU} / \mathrm{mL}$ in relation to the inoculum was found. ${ }^{14}$

\section{RESULTS}

\section{Physiochemical properties of CZ paste}

The FTIR spectra and DSC curves of CZ paste and its constituents are shown in Figure 1. Chloramphenicol had broad band at $3350 \mathrm{~cm}^{-1}$ which was attributed to $\mathrm{O}-\mathrm{H}$ bond stretching vibration, while at $3258 \mathrm{~cm}^{-1}$, 1658 and 1554 can be also clearly identified with $\mathrm{N}-\mathrm{H}, \mathrm{C}=\mathrm{O}$ stretching and $\mathrm{N}-\mathrm{H}$ bending. The peaks at 1521 and $1352 \mathrm{~cm}^{-1}$ are correlated with aromatic nitro compound. When several chlorine atoms are attached to one carbon atom, the band is usually more intense and the $\mathrm{C}$ - $\mathrm{Cl}$ vibration is observed at $778 \mathrm{~cm}^{-1}$ (Table 1). Zinc Oxide infrared spectra shows signature bands at 500 and $442 \mathrm{~cm}^{-1}$ attributed to $\mathrm{Zn}-\mathrm{O}$ stretching. ${ }^{15}$ The spectra of Eugenol exhibit its signature peaks at 3515, 3072 and 3002 and $1638 \mathrm{~cm}^{-1}$, corresponding to $\mathrm{O}-\mathrm{H}$ stretching, Ar-H stretching and vinyl $(\mathrm{C}=\mathrm{C})$ stretching. In addition, sharp peaks at 1610 and $1512 \mathrm{~cm}^{-1}$ were

Table 1: Frequency assignment of $\mathrm{CZ}$ paste components.

\begin{tabular}{|c|c|c|}
\hline Compound & $\begin{array}{l}\text { Wavenumber } \\
(\mathrm{cm}-1)\end{array}$ & $\begin{array}{l}\text { Vibrational mode assignment } \\
\text { and main contributions }\end{array}$ \\
\hline Zinc Oxide & 500 and $442 \mathrm{~cm}^{-1}$ & $\mathrm{Zn}-\mathrm{O}$ stretching \\
\hline \multirow[t]{7}{*}{ Chloramphenicol } & $3350 \mathrm{~cm}^{-1}$ & $\mathrm{O}-\mathrm{H}$ bond stretching vibration \\
\hline & $3263 \mathrm{~cm}^{-1}$ & $\mathrm{~N}-\mathrm{H}$ stretching \\
\hline & $1686 \mathrm{~cm}^{-1}$ & $\mathrm{C}=\mathrm{O}$ stretching (amida $\mathrm{I}$ ) \\
\hline & $1521 / 1350 \mathrm{~cm}^{-1}$ & $\mathrm{~N}-\mathrm{O}$ streching $\left(\mathrm{NO}_{2}-\mathrm{Ar}\right)$ \\
\hline & $1065 \mathrm{~cm}^{-1}$ & $\begin{array}{l}\text { C-O-C streching (primary } \\
\text { alcohol) }\end{array}$ \\
\hline & $1018 \mathrm{~cm}^{-1}$ & Ring bending \\
\hline & $845 \mathrm{~cm}^{-1}$ & $\begin{array}{l}\text { C-N Strech (out of plan NH- } \\
\text { bending) }\end{array}$ \\
\hline \multirow[t]{7}{*}{ CZ Paste } & $3350 \mathrm{~cm}^{-1}$ & $\mathrm{O}-\mathrm{H}$ bond stretching vibration \\
\hline & $3263 \mathrm{~cm}^{-1}$ & $\mathrm{~N}-\mathrm{H}$ stretching \\
\hline & $1687 \mathrm{~cm}^{-1}$ & $\mathrm{C}=\mathrm{O}$ stretching (amida $\mathrm{I}$ ) \\
\hline & $1518 / 1351 \mathrm{~cm}^{-1}$ & $\mathrm{~N}-\mathrm{O}$ streching $\left(\mathrm{NO}_{2}-\mathrm{Ar}\right)$ \\
\hline & $1062 \mathrm{~cm}^{-1}$ & $\begin{array}{l}\text { C-O streching (primary } \\
\text { alcohol) }\end{array}$ \\
\hline & $1018 \mathrm{~cm}^{-1}$ & Ring bending \\
\hline & $845 \mathrm{~cm}^{-1}$ & $\begin{array}{l}\text { C-N Streching (out of plan NH- } \\
\text { bending) }\end{array}$ \\
\hline \multirow[t]{5}{*}{ Eugenol } & $3515 \mathrm{~cm}^{-1}$ & O-H stretching \\
\hline & $3072 \mathrm{~cm}^{-1}$ & Ar-H stretching \\
\hline & $3002 / 1638 \mathrm{~cm}^{-1}$ & vinyl $(C=C)$ stretching \\
\hline & $1610 / 1512 \mathrm{~cm}^{-1}$ & $\begin{array}{c}\mathrm{C}=\mathrm{C} \text { stretching of the aromatic } \\
\text { moiety }\end{array}$ \\
\hline & $1265 \mathrm{~cm}^{-1}$ & C-O-C stretching \\
\hline
\end{tabular}


also found in eugenol, which can be due $\mathrm{C}=\mathrm{C}$ stretching of the aromatic moiety and at $1265 \mathrm{~cm}^{-1}$, which correspond to $\mathrm{C}-\mathrm{O}$ stretching. CZ paste presented a similar profile with the chloramphenicol spectrum with weaker absorbance because of the presence of other compounds.

DSC curve of Chloramphenicol has shown a sharp endotherm band at $152.63^{\circ} \mathrm{C}$ attributed to de melting point $(\mathrm{Tm})$ and in $\mathrm{CZ}$ curve the $\mathrm{Tm}$ of Chloramphenicol has been seen at $151.4^{\circ} \mathrm{C}$.

\section{Antimicrobial activity}

The mean diameters of the microbial growth inhibition zones for the pastes in the ADT are presented in Table 2. In general, the CZ paste and CTZ pastes presented similar inhibition zone diameters and were higher than the ZOE paste $(P<0.05)$.

CZ, CTZ and ZOE pastes inhibited the growth of all the tested microorganisms when compared to positive control (Figure 2A, B, C and D, respectively).

The bactericidal assessment test showed that the CZ paste and CTZ had positive bactericidal effect against all tested micro-organisms, while ZOE paste showed no effect.

\section{DISCUSSION}

$\mathrm{CZ}$ paste was developed as an alternative material for pulpectomies in primary teeth from a modification of CTZ paste by removing tetracycline of its formula. It also should be inserted just at the entrance of root canals and perhaps could be used in both anterior and posterior teeth, without the disadvantage of staining tooth structure promoted by tetracycline in the first formulation. However, further studies are necessary to establish this formulation and randomised clinical studies must be carried out in order to compare $\mathrm{CZ}$ paste with other techniques recommended in the literature.

In order to describe physiochemical properties of CZ paste, FTIR and DSC tests were performed. FTIR test describe several interactions between the drug and active molecules to analyse the spectra of each component of the formula. ${ }^{16}$ These substances presented several absorption peaks as described. The paste $\mathrm{CZ}$ presented similar profile to the chloramphenicol spectrum with weaker absorbance because of the other components of the paste, moreover, shifting also was not observed indicating no significative interactions between Zinc Oxide, Chloramphenicol and Eugenol. Sterren et al. ${ }^{17}$ reported possible molecular interactions and changes in solid-state forms into Chloramphenicol and different Amino Acids.
The bands of the solid system combination resulted in no interactions between the pure active ingredients while the antimicrobial activity of the antibiotic was preserved.DSC thermograms of Chloramphenicol and $\mathrm{CZ}$ paste demonstrated that the incorporation of particles to use as a paste changed a little the endothermic transition temperature. The displacement may have been caused due to the presence of the other paste components. The thermal decomposition of Chloramphenicol carried out at $258^{\circ} \mathrm{C}$. The DSC curve of CZ did not show a band of zinc oxide because its thermal decomposition occurs over $600^{\circ} \mathrm{C}$. However, the $\mathrm{CZ}$ curve has shown bands at $258^{\circ} \mathrm{C}$ and $313^{\circ} \mathrm{C}$ that correspond the thermal decomposition of chloramphenicol and eugenol. This could indicate that there were no interactions between the compounds, corroborating the FTIR results, corroborating to a previous study that showed that the combination of Chloramphenicol/Amino Acids had the melting endotherm temperature preserved and there was no interaction between them. ${ }^{17} \mathrm{CTZ}$ paste contains zinc oxide eugenol and two broad-spectrum antibiotics: tetracycline and chloramphenicol. It presents an effective antimicrobial activity, ${ }^{18}$ biocompatibility ${ }^{19}$ and satisfactory clinical and radiographic results. ${ }^{9,10}$ Besides this, the blood cellularity interface in the tooth socket of primary molars treated with CTZ paste is similar to those of healthy, exfoliated teeth and physiologically different from untreated decayed teeth. ${ }^{20}$ Primary teeth with necrotic pulps present polymicrobial infections. There is a predominance for anaerobic (facultative and moderate) species, gram-positive cocci and gram-negative coccobacilli. ${ }^{21}$ The micro-organisms used were referenced in other studies and are representative of the microbiota of primary molars with necrotic pulps. ${ }^{18}$ CZ paste and CTZ paste presented a similar antimicrobial activity, which

Table 2: Inhibition zone diameters (in $\mathrm{mm}$ ) provided by ADT.

\begin{tabular}{cccc}
\hline \multirow{2}{*}{ Tested bacteria } & CZ Paste & CTZ Paste & ZOE Paste \\
\cline { 2 - 4 } & Mean (S.D.) & Mean (S.D.) & Mean (S.D.) \\
\hline E. faecalis & $36.0(3.5)^{\mathrm{c}}$ & $34.3(4.0)^{\mathrm{c}}$ & $24.0(2.0)^{\mathrm{a}, \mathrm{b}}$ \\
S. aureus & $33.0(1.7)^{\mathrm{c}}$ & $30.0(0.0)^{\mathrm{c}}$ & $11.3(1.2)^{\mathrm{a}, \mathrm{b}}$ \\
P. aeruginosa & $32.0(0.0)^{\mathrm{c}}$ & $30.3(2.3)^{\mathrm{c}}$ & $11.3(0.6)^{\mathrm{a}, \mathrm{b}}$ \\
\hline
\end{tabular}

S.D. stands for Standard deviation.

Inter-pastes significant difference following an ANOVA and Bonferroni's posthoc test $(P<0.05)$. $\mathbf{a}$ - difference from the CZ Paste, $\mathbf{b}-$ from the CTZ paste and $\mathbf{c}-$ from the ZOE paste.
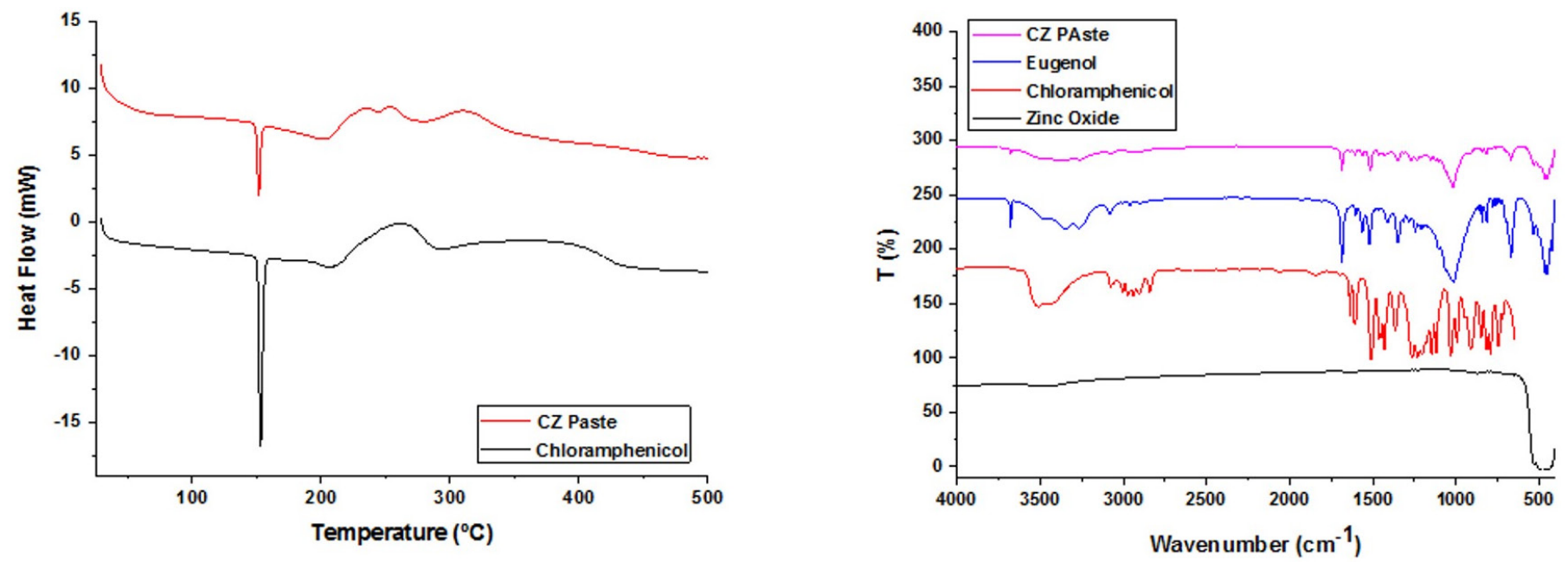

Figure 1: FTIR Spectra of CZ paste, Chloramphenicol, Zinc oxide and Eugenol and DSC curves of CZ paste, Chloramphenicol. 


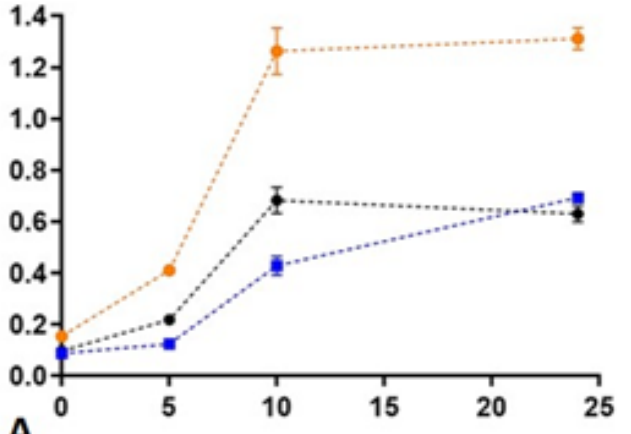

A

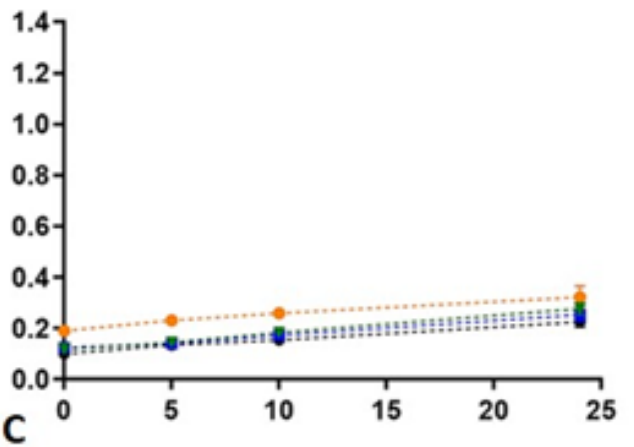

-๑-. E. faecalis

-n.- S. aureus
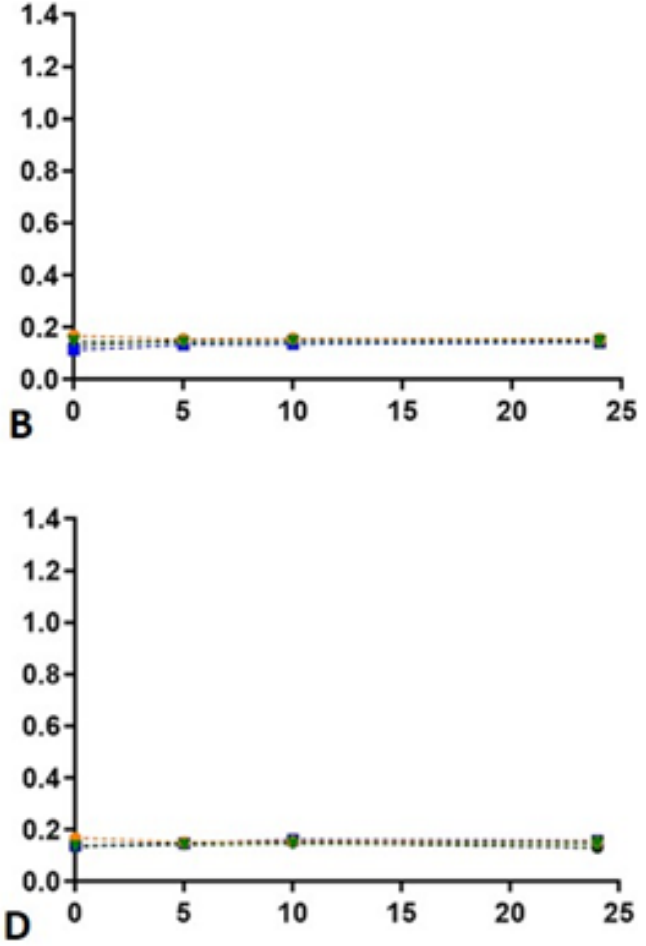

-... P. aeruginosa

.-.-. Negative control

Figure 2: Antimicrobial activity of the pastes in the DCT according to time (h). Each point in the growth curve expresses the mean \pm SEM optical density (OD) values obtained for four wells. A - Bacterial growth (positive control), B - CZ paste test, $C-C T Z$ paste test and D - ZOE paste test.

was higher than ZOE paste in both agar diffusion and direct contact tests. This corroborates with Amorim et al. ${ }^{18}$ which used the same method and observed that CTZ paste had a more effective antimicrobial activity than ZOE paste for all the micro-organisms. Tetracycline and chloramphenicol are bacteriostatic antibiotics that target the protein synthesis of Gram-positive and Gram-negative bacteria and have limited synergy. ${ }^{22,23}$ The absence of synergistic activity of that combination could explain why the CTZ paste did not present significantly better results than the CZ paste.

On the direct contact test ZOE paste showed a bacteriostatic effect; however, it presented no bactericidal effect on the growth of the micro-organisms afterwards, which differs from the study by Heyder et al..$^{13}$ which found that zinc oxide eugenol cement led to a significant reduction in the colony-forming units of E. faecalis, F. nucleatum and $P$. gingivalis. This may have occurred due to the fact that $\mathrm{ZOE}$ paste loses its antimicrobial action once it sets. ${ }^{24}$ One of the goals of paediatric dentistry is to perform endodontic treatment in primary teeth to maintain it function during the biological cycle. ${ }^{1,4}$ Traditional pulpectomy procedure in primary molars with necrotic pulp requires instrumentation of root canals system, disinfection with antimicrobial irrigants solutions and filling with absorbable and antibacterial materials. ${ }^{1,4,5} \mathrm{ZOE}$ paste is a traditional and largely recommended material for conventional treatments involving root canal instrumentation of the primary teeth. ${ }^{1,4}$ Its antibacterial effect is mainly attributed to the action of eugenol that causes protein denaturation. ${ }^{5,10,24}$ It is assumed that in view of the anatomical complexity of primary molars, its action is not sufficient enough to reduce the bacterial contamination and the use of antimicrobial irrigating substances is mandatory when instrumentation is performed. ${ }^{25}$

\section{CONCLUSION}

CZ paste could be an alternative for endodontic treatment of primary teeth with necrotic pulp.

\section{ACKNOWLEDGEMENT}

We acknowledge UFPI (Universidade Federal do Piauí), CNPq (Conselho Nacional para Desenvolvimento Científico e Tecnológico) and FAPEPI (Fundação de Amparo à Pesquisa do Estado do Piauí, Brazil) for the financial support, as well as to Professor Francisca Lúcia de Lima and post-graduation student Ellen Maria Matos de Andrade for their help with microbiological procedures. This work was granted by FAPEPI/ SESAPI/MS/CNPq 003/2013.

\section{CONFLICT OF INTEREST}

The authors declare that there is no conflict of interest.

\section{ABBREVIATIONS}

mm: milimetre; cm: centimetre; $\mu \mathrm{L}$ : microlitre; $\mathbf{m L}$ : millilitre; mg: milligram; min: minute; ${ }^{\circ} \mathbf{C}$ : degree celsius; hr: hour; $\mathbf{C F U}$ : colonyforming unity. 


\section{REFERENCES}

1. American Academy on Pediatric Dentistry. Pulp Therapy for Primary and Immature Permanent Teeth. Pediatr Dent. 2017;239(6):325-33.

2. Srivastava S, Alrogaibah NA, Aljarbou G. Cone-beam computed tomographic analysis of middle mesial canals and isthmus in mesial roots of mandibular first molars-prevalence and related factors. J Conserv Dent. 2018;21(5):526-30.

3. American Academy on Pediatric Dentistry. Management of the Developing Dentition and Occlusion in Pediatric Dentistry. Pediatr Dent. 2017;39(6):334-47.

4. Smaïl-Faugeron V, Glenny AM, Courson F, Durieux P, Muller-Bolla M, Fron $\mathrm{CH}$. Pulp treatment for extensive decay in primary teeth. Cochrane Database Syst Rev. 2018;5:CD003220.

5. Najjar RS, Alamoudi NM, El-Housseiny AA, AlTuwirqi AA, Sabbagh HJ. A comparison of calcium hydroxide/iodoform paste and zinc oxide eugenol as root filling materials for pulpectomy in primary teeth: A systematic review and meta-analysis. Clin Exp Dent Res. 2019;5(3):294-310.

6. Cappiello J. Tratamientos pulpares en incisivos primários. Rev Circ Od Ros. $1964 ; 52(4): 133-45$

7. Cappiello J. Nuevos enfoques en odontología infantil. Odont Urug. 1967;23:2330.

8. Kontakiotis EG, Filippatos CG, Tzanetakis GN, Agrafioti A. Regenerative endodontic therapy: A data analysis of clinical protocols. J Endod. 2015:41(2):146-54

9. DeDeus DeMoura FL, DeLima MD, Lima CC, Machado JI, DeMoura MS, et al. Endodontic treatment of primary molars with antibiotic paste: A report of 38 cases. J Clin Pediatr Dent. 2016;40(3):175-7.

10. Luengo-Fereira J, Ayala-Jiménez S, Carlos-Medrano LE, Toscano-García I, Anaya-Álvarez M. Clinical and Radiographic Evaluation of Formocresol and Chloramphenicol, Tetracycline and Zinc Oxide-Eugenol Antibiotic Paste in Primary Teeth Pulpotomies: 24 month follow up. J Clin Pediatr Dent. 2019:43(1):16-21.

11. Montero-Miralles P, Martín-González J, Alonso-Ezpeleta $O$, Jiménez-Sánchez MC, Velasco-Ortega E, Segura-Egea JJ. Effectiveness and clinical implications of the use of topical antibiotics in regenerative endodontic procedures: A review. Int Endod J. 2018;51(9):981-8.

12. Gomes BPFA, Ferraz CCR, Vianna ME, Rosalen PL, Zaia AA, Teixeira FB, et al. In vitro antimicrobial activity of calcium hydroxide pastes and their vehicles against selected microorganisms. Braz Dent J. 2002;13(3):155-61.

13. Heyder M, Kranz S, Völpel A, Pfister W, Watts DC, Jandt KD, et al. Antibacterial effect of different root canal sealers on three bacterial species. Dent Mater. 2013;29(5):542-9.

14. French GL. Bactericidal agents in the treatment of MRSA infections-the potential role of daptomycin. J Antimicrob Chemother. 2006;58(6):1107-17.

15. Bhat P, Kumar SKN, Nagaraju P. Synthesis and characterization of ZnO-MWCNT nanocomposites for 1-butanol sensing application at room temperature. Physica B: Condensed Matter. 2019;570:139-47.

16. Alhashimi RA, Mannocci F, Sauro S. Bioactivity, cytocompatibility and thermal properties of experimental Bioglass-reinforced composites as potential rootcanal filling materials. J Mech Behav Biomed Mater. 2017;69:355-61.

17. Sterren VB, Aiassa V, Garnero C, Linck YG, Chattah AK, Monti GA, et al Preparation of Chloramphenicol/Amino Acid Combinations Exhibiting Enhanced Dissolution Rates and Reduced Drug-Induced Oxidative Stress. AAPS Pharm Sci Tech. 2017;18(8):2910-8.

18. Amorim LFG, Toledo OA, Estrela CRA, Decurcio DA, Estrela C. Antimicrobial analysis of different root canal filling pastes used in pediatric dentistry by two experimental methods. Braz Dent J. 2006;17(4):317-22.

19. Lima CC, Conde JAM, Rizzo MS, Moura RD, Moura MS, Lima MD, et al. Biocompatibility of root filling pastes used in primary teeth. Int Endod $\mathrm{J}$. 2015;48(5):405-16.

20. Moura LFAD, Lima MDM, Lima CCB, Bandeira AVL, Moura MS, Conde JAM, et al. Cellular profile of primary molars with pulp necrosis after treatment with antibiotic paste. Int J Exp Pathol. 2018:99(5):264-8.

21. Nelson-Filho P, Ruviére DB, DeQueiroz AM, DePaula-Silva FWG, Silva RABD Lucisano MP, et al. Comparative Molecular Analysis of Gram-Negative Bacteria in Primary Teeth with Irreversible Pulpitis or Periapical Pathology. Pediatr Dent. 2018;40(4):259-64

22. How SJ, Hobson D, Hart CA, Webster RE. An in-vitro investigation of synergy and antagonism between antimicrobials against Chlamydia trachomatis. J Antimicrob Chemother. 1985;15(5):533-8.

23. Pinheiro ET, Gomes BP, Drucker DB, et al. Antimicrobial susceptibility of Enterococcus faecalis isolated from canals of root filled teeth with periapical lesions. Int Endod J. 2004;37(11):756-63.

24. Wright KJ, Barbosa SV, Araki K, Spångberg LS. In vitro antimicrobial and cytotoxic effects of Kri 1 paste and zinc oxide-eugenol used in primary tooth pulpectomies. Pediatr Dent. 1994;16(2):102-6.

25. Pozos-Guillen A, Garcia-Flores A, Esparza-Villalpando V, Garrocho-Rangel A Intracanal irrigants for pulpectomy in primary teeth: A systematic review and meta-analysis. Int J Paediatr Dent. 2016:26(6):412-25.

Article History: Submission Date : 27-06-2020; Revised Date : 18-07-2020; Acceptance Date : 28-08-2020

Cite this article: Machado JIAG, Oliveira RWG, Oliveira ALM, Quelemes PV, Lima MDM, Moura MS, et al. Evaluation of a Novel Endodontic Paste for Primary Teeth with Necrotic Pulp. JYoung Pharm. 2020;12(3):221-5. 